\title{
Survival of Own-rooted and Budded 'Redhaven' Trees on a Peach Tree Short Life Site
}

\author{
Gregory L. Reighard ${ }^{1}$, William A. Watson ${ }^{2}$, D.C. Coston ${ }^{3}$, and \\ John D. Ridley ${ }^{4}$ \\ Clemson University, Clemson, SC 29434 \\ Additional index words. Prunus persica, rootstocks
}

Vegetative propagation of peach cultivars has been proposed as a practical system to economically produce large numbers of peach trees for high-density plantings (Couvillon and Erez, 1980; Coston et al., 1983; Matta and Vadhwa, 1987). Own-rooted trees have also been reported to withstand water stress better (Couvillon et al., 1989) than cultivars budded to traditional seedling rootstocks such as 'Lovell' or 'Halford'. One major limiting factor to peach production in the southeastem United States, however, is peach tree short life (PTSL). This disease syndrome is characterized by tree death in early spring from cold injury and/or bacterial canker (Pseudomonas syringae pv.syringae van Hall) and is significantly influenced by rootstocks susceptible to the ring nematode (Criconemella xenoplax (Raski) Luc \& Raski) (Nyczepir et al., 1983). Reviews of earlier PTSL research by Brittain and Miller (1978) and Ritchie and Clayton (1981) concluded that cultivars budded to 'Lovell' or 'Halford' seedlings survived longer on short life sites than on other rootstocks (e.g., 'Nemaguard'). Today, 'Lovell' remains the recommended rootstock for PTSL sites. The

Received for publication 24 July 1989. Technical contribution no. 2994 of the South Carolina Agricultural Experiment Station. The cooperation of R.M. Watson is gratefully acknowledged. The cost of publishing this paper was defrayed in part by the payment of page charges. Under postal regulations, this paper therefore must be hereby marked advertisement solely to indicate this fact:

${ }^{1}$ Assistant Professor of Horticulture. Sandhill Research and Education Center, Elgin, SC 29045.

${ }^{2}$ County Extension Director. Current address: Box 509. Edgefield, SC 29824.

${ }^{3}$ Association Director, South Carolina Agr. Expt. Sta.

${ }^{4}$ Professor of Horticulture. decision to use own-rooted peach cultivars in the southeast must then be carefully weighed against the potential risk of increased tree mortality from PTSL. This paper reports on the relationship between ownrooted and budded 'Redhaven' trees and the incidence of PTSL in South Carolina.

A high-density peach orchard was planted on a former peach site at the R.M. Watson and Sons farm near Johnston, S.C., in Feb. 1984. The experimental design of the orchard was a randomized block with six-tree plots and 12 replicates. Treatments were ownrooted 'Redhaven' trees (OR) and 'Redhaven' budded to 'Lovell' seedlings planted at a spacing of $2.3 \times 4.3 \mathrm{~m}$. Soil was an Orangeburg sandy loam (fine-loamy, siliceous, thermic Typic Palequults) that was pre-plant disked, subsoiled, and limed, but not fumigated, since no PTSL had occurred in the previous orchard. Trees were trained to a central leader because initially the objective was to evaluate fruit quality and yield in comparison with a traditional open-vase system. Overhead irrigation was applied when needed until fruit harvest. All dormant pruning was done in February. In Spring 1988 and 1989, a significant amount of tree mortality from PTSL occurred. In May 1989, trees were rated either for tree death from PTSL (cold injury or bacterial canker) or alive with or without primary limbs killed by bacterial canker. Percent tree survival and mortality data were recorded and arcsin transformed for analysis of variance.

'Redhaven' trees on 'Love11 rootstock had both significantly higher survival $(P<0.05)$ and lower PTSL mortality from cold injury and bacterial canker $(P<0.05)$ than OR 'Redhaven' trees. After five growing seasons, 38 of $72(53 \%)$ 'Redhaven'/'Lovell' trees were alive compared to 17 of $72(24 \%)$
OR 'Redhaven'. Mortality from PTSL for budded and OR 'Redhaven' was $33(46 \%)$ and $51(71 \%)$ trees, respectively. In addition, own-rooted trees killed above-ground by PTSL produced few sprouts, possibly due to an overall tree weakening by bacterial canker or secondary fungal pathogens (Polyporous spp.). Of the surviving trees, 13 of the $38(34 \%)$ budded trees and 8 of 17 $(47 \%)$ OR trees had at least one primary branch killed by bacterial canker.

The data show that a greater number of OR 'Redhaven' trees died from PTSL within the first 5 years than 'Redhaven'/'Lovell' trees. Additional data from another study (unpublished data) on a PTSL site at the Sandhill Research and Education Center in Pontiac, S.C., showed that, after 6 years, OR 'Redglobe' trees had significantly higher $(P<0.01)$ PTSL mortality $(76 \%)$ than 'Redglobe'/'Halford' (36\%). Both studies indicate that own-rooted peach cultivars should first be screened for susceptibility to ring nematodes, bacterial canker, and other factors associated with PTSL before planting on PTSL sites. Otherwise, early mortality of own-rooted cultivars may be significantly greater than that of the same cultivars budded to recommended seedling rootstocks.

\section{Literature Cited}

Brittain, J.A. and R.W. Miller, Jr. (eds.). 1978. Managing peach tree short life in the Southeast. South Carolina Agr. Ext. Serv. Circ. 585.

Coston, D.C., G.W. Krewer, R.C. Owings, and E.G. Denny. 1983. Air rooting of-peach semihardwood cuttings. HortScience 18:323324

Couvillon, G.A. and A. Erez. 1980. Rooting, survival, and development of several peach cultivars propagated from semihardwood cuttings. HortScience 15:41-43.

Couvillon, G.A., M. Rieger, R. Harrison, J. Daniell, and J.G. Aparisi. 1989. Stress-mediated responses of own-rooted peach cultivars: Response to water stress in comparison to several commonly used peach rootstocks. Acta Hort. 243:221-230

Matta, F.B. and O.P. Vadhwa. 1987. Rooting and survival of semihardwood peach cuttings under field conditions. Miss. Agr. For. Expt. Sta. Res. Rpt. 12(14):1-3.

Nyczepir, A.P., E.I. Zehr, S.A. Lewis, and D.C. Harshman. 1983. Short life of peach trees induced by Criconemella xenoplax. Plant Dis. 67:507-508

Ritchie, D.F. and C.N. Clayton. 1981. Peach tree short life: A complex of interacting factors. Plant Dis. 65:462-469. 